\title{
Varietal Screening of French Bean (Phaseolus vulgaris L.) Varieties against Spider Mite, Tetranychus urticae Koch under Field Condition
}

\author{
Chauhan Rinkikumari and Abhishek Shukla*
}

\author{
Department of Entomology, N. M. College of Agriculture, \\ Navsari Agricultural University, Navsari-396450, Gujarat, India \\ *Corresponding author
}

\begin{tabular}{|c|c|}
\hline & A B S T R A C T \\
\hline \multicolumn{2}{|l|}{ Keywords } \\
\hline $\begin{array}{l}\text { Screening, French } \\
\text { bean, } T \text {. urticae, } \\
\text { open field. }\end{array}$ & \multirow{3}{*}{$\begin{array}{l}\text { An experiment was carried out to screen twelve French bean varieties } \\
\text { against two spotted spider mite, } T \text {. urticae under open field condition. } \\
\text { Among the twelve cultivars screened for their reaction to spider mite } T \text {. } \\
\text { urticae, the descending order of these French bean varieties were as Gujarat } \\
\text { Rajmah>Arka Komal> HUR-137 > IPR-98-5 >Suvidha }>\text { Arka Bold } \\
>\text { ArkaAroop }>\text { IVFB- } 1>\text { HUR-203 }>\text { PDR-14 }>\text { HUR-15 }>\text { IPR-98-31. }\end{array}$} \\
\hline Article Info & \\
\hline $\begin{array}{l}\text { Accepted: } \\
\text { 12 March } 2017 \\
\text { Available Online: } \\
10 \text { April } 2017\end{array}$ & \\
\hline
\end{tabular}

\section{Introduction}

French bean is one of the very profitable cool season legume vegetable grown for its tender pods, shelled green beans and dry beans. The dry seed type varieties are called as "Rajmah" in India. It is valued for its protein rich (23\%) seeds. They are also rich in calcium, phosphorus and iron. Globally French bean is cultivated on about $28 \mathrm{~m}$ ha with a production of 19 million tonnes. In India, it is grown on an area of about 1 lakh ha mainly in the states of Maharashtra (60,000 ha), Jammu and Kashmir (10,000 ha), Himachal Pradesh and Uttar Pradesh Hills, Nilgiri (Tamil Nadu) and Palni (Kerala) hills, Chickmagalur (Karnataka) and Darjeeling hills (West Bengal). In Gujarat, it is grown near the metro cities like Surat, Baroda, Ahmedabad, and Rajkot under poly houses as well as in open field for continuous supply of its fresh tender pods for vegetable purpose. Indiscriminate use of pesticides has not only caused the resistance in phytophagous mites but also has polluted the environment. Integrated pest management is the solution to the problems of the resistance and environmental pollution. Use of resistant varieties is a component of Integrated Pest Management. Heavy incidence of insect and mite pests has been observed under protected as well as in open field on French bean due to congenial environmental conditions. Spider mite belongs to the family Tetranychidae are among the destructive pests of many agrihorticultural crops in many parts of the world. Tetranychus urticae Koch, commonly known as two spotted red spider mite, is 
acosmopolitan mite pest reported as serious pest on many economically important plants like French bean, cucurbits, cotton, alfalfa, flowers etc. (Meyer and Rodriguez, 1966; Manjulata et al., 2002). Two spotted spider mite infests the underside of leaves, where profuse webbing may be present. The rapid developmental rate, short generation time and high net reproductive rate of $T$. urticae allows them to achieve damaging population levels very quickly when growth conditions are good, resulting in an equally rapid decline of host plant quality (Najafabadi, 2012). Host plant resistance is one of the important component of IPM, the search for resistant varieties starts with screening of available plant materials of diverse origin. The present study undertaken to evaluate the French bean varieties for identifying the possible resistant varieties against infestation of $T$. urticae.

\section{Materials and Methods}

Twelve French bean varieties were evaluated for their reaction to $T$. urticae in open field condition. The seeds of all twelve varieties were sown in separate bed on $22^{\text {nd }}$ December 2015. All standard agronomic practices were followed for the sowing. Sowing of varieties was done in open field and utilized for screening against spider mite, $T$. urticae. Weekly observation on the population of spider mite, $T$. urticae was taken commencing from a fortnight after germination and continued throughout entire crop period. For the purpose of investigation five plants were randomly selected each time and each variety replication wise. Population densities of spider mite was assessed by taking three random leaves representing top, middle and bottom canopy of the plant from respective variety. Thus, in all 15 leaves/replication were observed at one time for each variety. The plucked leaves were held in separate polythene bags which were properly labelled and brought to Acarology laboratory for examination under stereo binocular microscope. On each leaf, the spider mite, $T$. urticae was counted (mobile stages) under stereo binocular microscope on $2 \mathrm{~cm}^{2}$ leaf area. The data on numerical count were averaged and converted to per unit area (per leaf bit or per leaf) and analysed statistically using Completely Randomized Design (CRD). On the basis of the average number of mites present on each leaf of French bean, the reactions of plant were worked out to spider mite. To enumerate host plant resistance based on morphophysical characters of leaves of all the twelve cultivars of French bean, the observations for morphological characters of leaves viz., length of leaf hair (mm), plant height $(\mathrm{cm})$, number of leaves per plant, thickness of leaf lamina $(\mathrm{mm})$ and density of leaf hairs were recorded in the same way as done in the sampling of spider mites described during crop period. The numbers of hairs was converted in $2 \mathrm{~cm}^{2}$ area from upper and lower surface of leaf was recorded from the middle area of the leaf. The thickness of leaf lamina was recorded with digital Vernier Callipers instrument by placing two equal width acrylic sheets, and places the French bean leaves in between them. The measurement was taken with constant temperature and pressure during observation, from middle area of the leaf. The number of leaves was measured by selecting leaves randomly from upper, middle and bottom portion of the plants. The plant height was measured with the help of meter rod in $\mathrm{cm}^{2}$. The length of leaf hair, and leaf hair density was recorded with Scope Software.

\section{Results and Discussion}

Population of spider mite, T. urticae on various French bean varieties

During the period of present investigations, twelve French bean varieties were screened for their reaction to spider mite, T. urticae 
under open field condition, the observations on the population of $T$. urticae were recorded at weekly interval from January 2015 to June 2015. It is seen from the population data presented in Table 2 that in $1^{\text {st }}$ SMW the population of spider mite ranged from 0.93 mites per $2 \mathrm{~cm}^{2}$ leaf to 5.53 mites per $2 \mathrm{~cm}^{2}$ leaf. The lowest population was recorded on IPR-98-31 and the highest population was recorded on HUR-137. In $2^{\text {nd }}$ SMW the lowest spider mite population were recorded on PDR-14 (1.53 mites/2 $\mathrm{cm}^{2}$ leaf), whereas the highest spider mite population were recorded on Gujarat Rajmah (6.93 mites/2 $\mathrm{cm}^{2}$ leaf) followed by 6.27 and 5.13 mites per $2 \mathrm{~cm}^{2}$ leaf on various cultivar viz., ArkaKomal and Hur-137. During the $3^{\text {rd }}$ SMW the intensity of spider mite population was increased gradually and ranging between 1.37 to 6.03 mites per $2 \mathrm{~cm}^{2}$ leaf whereas in $4^{\text {th }}$ SMW the spider mite population were ranging between from 1.23 to 6.46 mites per 2 $\mathrm{cm}^{2}$ leaf, whereas, in the $5^{\text {th }}$ SMW the spider mite population were fluctuate on some of the French bean cultivar, the population of spider mite was increased whereas in some of the cultivar the population of spider mite were decreased. In French bean cultivars IPR-98-5, IPR-98-31, Arka Aroop, Arka Bold, HUR137, PDR-14 the spider mite population was decreased and on HUR-15, ArkaKomal, Gujarat Rajmah, Suvidha, HUR-203 it increased. During the $6^{\text {th }}$ SMW the intensity of infestation ranged between 1.13 to 4.47 mites per $2 \mathrm{~cm}^{2}$ leaf whereas in the $7^{\text {th }} \mathrm{SMW}$ the population of spider mite were ranged between 1.47 to 7.33 mites per $2 \mathrm{~cm}^{2}$ leaf, whereas in $8^{\text {th }}$ SMW the population were ranged between 0.80 to 4.73 mites per $2 \mathrm{~cm}^{2}$ leaves. During $9^{\text {th }}$ to $11^{\text {th }}$ SMW the spider mite population was gradually increased. In $12^{\text {th }}$ SMW the population of spider mite fluctuates, on some of the French bean varieties, the spider mite population was increased, while in some of the varieties like IVFB -1, IPR-98-31, Suvidha etc. were decreased. The highest population of spider mite was recorded during $11^{\text {th }}, 15^{\text {th }}, 17^{\text {th }}, 18^{\text {th }}$, $21^{\text {st }}$, and $23^{\text {rd }}$ SMW. On the basis of overall mean of spider mite population on different French bean varieties the descending order were: Gujarat Rajmah>ArkaKomal> HUR$137>$ IPR-98-5 >Suvidha>Arka Bold $>$ ArkaAroop > IVFB-1 > HUR-203 > PDR-14 $>$ HUR-15 > IPR-98-31. In past, Ramireddy et al., (2004) recorded least incidence of $T$. urticae on Angel Bell and highest on Collection No-10 of chrysanthemum germplasm. According to Hole and Salunkhe (2005) the rose cultivars Rajhans was found to be the most promising recording the lowest population of mites, while cultivar Arjun recorded the maximum number of mites. Bhusal (2011) reported Jaya and IIHR-6 varieties of chrysanthemum less susceptible to T. urticae whereas, Toke (2010) reported rose variety Shakira as tolerant to $T$. urticae under poly house conditions. Further in recently, Shukla and Radadia (2015) also reported that among the carnation varieties the variety Domingo was highly tolerant to spider mite, while variety Rubisco was highly susceptible to spider mite attack. Thus, more or less support the present findings.

\section{Morphological character of French bean varieties}

During the experiment period, the various morphological characters of all the twelve French bean varieties were recorded. The various characters were presented in the Table 3. They were just discussed in the light of incidence of mean number of spider mite population. The data recorded were plant height, number of leaves per plant, thickness of leaves, length of leaf hair and density of hair on leaf surface. Out of various parameters contributing towards final yield of the crop, the number of leaves per plant and plant height is of prime importance. 
Table.1 Population of spider mite, T. urticae French bean varieties under open field condition (year 2015)

\begin{tabular}{|c|c|c|c|c|c|c|c|c|c|c|c|c|}
\hline \multirow[t]{2}{*}{ SMW } & \multicolumn{12}{|c|}{ Varieties of French bean } \\
\hline & IVFB-1 & IPR-98-5 & ArkaAroop & $\begin{array}{l}\text { Arka } \\
\text { Bold }\end{array}$ & PDR-14 & HUR-15 & $\begin{array}{l}\text { IPR-98- } \\
31\end{array}$ & $\begin{array}{l}\text { ArkaKo } \\
\text { mal }\end{array}$ & $\begin{array}{l}\text { Gujarat } \\
\text { Rajmah }\end{array}$ & HUR-137 & Suvidha & HUR-203 \\
\hline 1. & 2.33 & 3.67 & 3.07 & 2.73 & 2.00 & 1.20 & 0.93 & 3.80 & 5.13 & 5.53 & 2.93 & 1.67 \\
\hline 2. & 4.00 & 3.67 & 3.00 & 4.27 & 1.53 & 2.20 & 1.80 & 6.27 & 6.93 & 5.13 & 4.20 & 3.33 \\
\hline 3. & 3.17 & 3.67 & 3.03 & 3.50 & 1.77 & 1.70 & 1.37 & 5.03 & 6.03 & 5.33 & 3.57 & 2.50 \\
\hline 4. & 2.84 & 3.70 & 4.31 & 4.97 & 1.80 & 1.23 & 1.48 & 5.39 & 6.46 & 4.28 & 2.42 & 2.61 \\
\hline 5. & 4.33 & 3.07 & 3.07 & 3.20 & 1.53 & 1.40 & 1.20 & 5.60 & 7.20 & 3.53 & 2.93 & 3.33 \\
\hline 6. & 2.87 & 2.87 & 2.93 & 4.27 & 1.67 & 1.13 & 1.40 & 4.00 & 4.47 & 3.20 & 3.60 & 4.00 \\
\hline 7. & 4.53 & 4.93 & 4.20 & 3.73 & 2.20 & 1.53 & 1.47 & 5.40 & 7.33 & 4.60 & 4.40 & 3.07 \\
\hline 8. & 2.60 & 3.07 & 3.00 & 4.27 & 1.80 & 1.27 & 0.80 & 4.00 & 4.73 & 3.13 & 3.60 & 4.20 \\
\hline 9. & 4.27 & 5.07 & 4.07 & 3.47 & 2.07 & 1.40 & 1.47 & 5.33 & 7.33 & 4.53 & 4.53 & 3.20 \\
\hline 10. & 3.80 & 4.93 & 4.20 & 3.73 & 2.20 & 1.53 & 1.27 & 4.80 & 7.20 & 4.53 & 4.27 & 2.80 \\
\hline 11. & 4.53 & 5.07 & 4.20 & 3.80 & 1.80 & 1.47 & 1.60 & 4.93 & 8.13 & 4.53 & 440 & 3.07 \\
\hline 12. & 3.80 & 4.93 & 4.20 & 3.73 & 2.20 & 1.53 & 1.27 & 4.80 & 7.20 & 4.53 & 4.27 & 2.80 \\
\hline 13. & 3.80 & 4.93 & 4.20 & 3.73 & 2.20 & 1.53 & 1.27 & 4.80 & 7.20 & 4.53 & 4.27 & 2.80 \\
\hline 14. & 2.60 & 3.07 & 3.00 & 4.27 & 1.80 & 1.27 & 0.80 & 4.00 & 4.73 & 3.13 & 3.60 & 4.20 \\
\hline 15. & 4.53 & 5.07 & 4.20 & 3.80 & 1.80 & 1.47 & 1.60 & 4.93 & 8.13 & 4.53 & 4.40 & 3.07 \\
\hline 16. & 3.80 & 4.93 & 4.20 & 3.73 & 2.20 & 1.53 & 1.27 & 4.80 & 7.20 & 4.53 & 4.27 & 2.80 \\
\hline 17. & 4.53 & 5.07 & 4.20 & 3.80 & 1.80 & 1.47 & 1.60 & 4.93 & 8.13 & 4.53 & 4.40 & 3.07 \\
\hline 18. & 4.53 & 5.07 & 4.20 & 3.80 & 1.80 & 1.47 & 1.60 & 4.93 & 8.13 & 4.53 & 4.40 & 3.07 \\
\hline 19. & 3.80 & 4.93 & 4.20 & 3.73 & 2.20 & 1.53 & 1.27 & 4.80 & 7.20 & 4.53 & 427 & 3.07 \\
\hline 20. & 3.80 & 4.93 & 4.20 & 3.73 & 2.20 & 1.53 & 1.27 & 4.80 & 7.20 & 4.53 & 4.27 & 3.07 \\
\hline 21. & 4.53 & 5.07 & 4.20 & 3.80 & 1.80 & 1.47 & 1.60 & 4.93 & 8.13 & 4.53 & 4.40 & 3.07 \\
\hline 22. & 2.60 & 3.07 & 3.00 & 4.27 & 1.80 & 1.27 & 0.80 & 4.00 & 4.73 & 3.13 & 3.60 & 4.220 \\
\hline 23. & 4.53 & 5.07 & 4.20 & 3.80 & 1.80 & 1.47 & 1.60 & 4.93 & 8.13 & 4.53 & 4.40 & 3.07 \\
\hline $\begin{array}{l}\text { Seasonal } \\
\text { Mean }\end{array}$ & $3.75 \pm 0.77$ & $4.34 \pm 0.87$ & $3.79 \pm 0.58$ & $3.83 \pm 0.43$ & $1.91 \pm 0.22$ & $1.46 \pm 0.21$ & $1.34 \pm 0.28$ & $4.84 \pm 0.58$ & $6.83 \pm 1.24$ & $4.35 \pm 0.67$ & $3.97 \pm 3.11$ & $3.11 \pm 0.59$ \\
\hline
\end{tabular}


Table.2 Reaction of French bean cultivars against T. urticae in open field condition

\begin{tabular}{|c|l|l|l|l|l|}
\hline S. No. & Cultivars & Min. & Max. & Mean \pm S. D. & Reaction to spider mite \\
\hline 1 & IVFB-1 & 2.33 & 4.53 & $3.75 \pm 0.77$ & Less Susceptible \\
\hline 2 & IPR-98-5 & 2.87 & 5.07 & $4.34 \pm 0.87$ & Medium Susceptible \\
\hline 3 & ArkaAroop & 2.93 & 4.31 & $3.79 \pm 0.58$ & Less Susceptible \\
\hline 4 & Arka Bold & 2.73 & 4.97 & $3.83 \pm 0.43$ & Less Susceptible \\
\hline 5 & PDR-14 & 1.53 & 2.20 & $1.91 \pm 0.22$ & Tolerant \\
\hline 6 & HUR-15 & 1.13 & 2.20 & $1.46 \pm 0.21$ & Tolerant \\
\hline 7 & IPR-98-31 & 0.80 & 1.80 & $1.34 \pm 0.28$ & Tolerant \\
\hline 8 & ArkaKomal & 3.80 & 6.27 & $4.84 \pm 0.58$ & Medium Susceptible \\
\hline 9 & Gujarat Rajmah & 4.47 & 8.13 & $6.83 \pm 1.24$ & Highly Susceptible \\
\hline 10 & HUR-137 & 3.13 & 5.53 & $4.35 \pm 0.67$ & Medium Susceptible \\
\hline 11 & Suvidha & 2.42 & 4.53 & $3.97 \pm 3.11$ & Less Susceptible \\
\hline 12 & HUR-203 & 1.67 & 4.20 & $3.11 \pm 0.59$ & Less Susceptible \\
\hline
\end{tabular}

Table.3 Biomorphological character of French bean cultivars in field condition

\begin{tabular}{|l|l|c|c|c|c|c|c|}
\hline $\begin{array}{l}\text { S. } \\
\text { No. }\end{array}$ & \multicolumn{1}{|c|}{$\begin{array}{c}\text { Name of } \\
\text { Cultivars }\end{array}$} & $\begin{array}{c}\text { Mite population } \\
\text { Mean } \pm \text { S. D. }\end{array}$ & $\begin{array}{c}\text { No. of leaves } \\
\text { per plant } \\
\text { Mean } \pm \text { S.D. }\end{array}$ & $\begin{array}{c}\text { Plant height } \\
(\mathrm{cm}) \\
\text { Mean } \pm \text { S.D. }\end{array}$ & $\begin{array}{c}\text { Thickness of leaf } \\
\text { lamina }(\mathrm{mm}) \\
\text { Mean } \pm \text { S.D. }\end{array}$ & $\begin{array}{c}\text { Length of } \\
\text { leaf hair } \\
(\mathrm{mm})(\mathrm{Mean})\end{array}$ & $\begin{array}{c}\text { Leaf hair } \\
\text { density }\left(\mathrm{cm}{ }^{2}\right) \\
\text { Mean } \pm \text { S.D. }\end{array}$ \\
\hline 1 & IVFB-1 & $3.75 \pm 0.77$ & $157.00 \pm 0.00$ & $51.00 \pm 2.00$ & $0.47 \pm 0.01$ & 0.04 & $41.33 \pm 1.15$ \\
\hline 2 & IPR-98-5 & $4.34 \pm 0.87$ & $151.67 \pm 2.89$ & $40.33 \pm 2.52$ & $0.43 \pm 0.01$ & 0.03 & $36.33 \pm 0.58$ \\
\hline 3 & ArkaAroop & $3.79 \pm 0.58$ & $159.33 \pm 0.58$ & $53.67 \pm 2.08$ & $0.51 \pm 0.02$ & 0.03 & $42.67 \pm 0.58$ \\
\hline 4 & Arka Bold & $3.83 \pm 0.43$ & $159.00 \pm 6.08$ & $52.33 \pm 1.53$ & $0.52 \pm 0.01$ & 0.03 & $43.00 \pm 1.00$ \\
\hline 5 & PDR-14 & $1.91 \pm 0.22$ & $165.67 \pm 4.04$ & $61.33 \pm 4.16$ & $0.62 \pm 0.01$ & 0.05 & $47.33 \pm 2.52$ \\
\hline 6 & HUR-15 & $1.46 \pm 0.21$ & $171.67 \pm 10.41$ & $63.00 \pm 1.00$ & $0.58 \pm 0.02$ & 0.04 & $43.00 \pm 1.00$ \\
\hline 7 & IPR-98-31 & $1.34 \pm 0.28$ & $171.67 \pm 7.64$ & $61.33 \pm 2.08$ & $0.62 \pm 0.01$ & 0.05 & $42.33 \pm 0.58$ \\
\hline 8 & ArkaKomal & $4.884 \pm 0.58$ & $158.33 \pm 7.64$ & $43.00 \pm 3.61$ & $0.46 \pm 0.01$ & 0.03 & $37.00 \pm 1.00$ \\
\hline 9 & Gujarat Rajmah & $6.83 \pm 0.1 .2$ & $140.00 \pm 5.00$ & $33.33 \pm 1.53$ & $0.35 \pm 0.01$ & 0.03 & $31.67 \pm 2.89$ \\
\hline 10 & HUR-137 & $4.35 \pm 0.67$ & $151.67 \pm 2.89$ & $42.67 \pm 3.21$ & $0.44 \pm 0.02$ & 0.03 & $37.33 \pm 1.15$ \\
\hline 11 & Suvidha & $3.97 \pm 0.58$ & $158.33 \pm 3.21$ & $51.67 \pm 3.51$ & $0.51 \pm 0.01$ & 0.03 & $38.33 \pm 0.58$ \\
\hline 12 & HUR-203 & $3.11 \pm 0.59$ & $153.33 \pm 0.58$ & $53.00 \pm 2.65$ & $0.51 \pm 0.01$ & 0.04 & $39.33 \pm 2.31$ \\
\hline
\end{tabular}


The spider mite population and the number of leaves per plant of different cultivars were recorded and it is evident from the Table 3 that the mean spider mite population was highest on Gujarat Rajmah $\left(6.83\right.$ mites $/ 2 \mathrm{~cm}^{2}$ leaf) in open field condition, that's why the spider mite infestation is considerably more, so the plant height, and number of leaves per plant, were recorded less so it is consider as highly susceptible cultivar in field condition. In comparison to the tolerant variety, the spider mite infestation is less and the plant grow healthy, so the plants having maximum numbers of leaves as well as the plant height was also high in comparison to other varieties of French bean grown in open field condition. So, the maximum number of leaves per plant and highest height were recorded in the cultivar PDR-14, HUR-15, and also in IPR98-31 in open field condition, while the minimum number of leaves and plant height were recorded on Gujarat Rajmah in open field condition. Thickness of leaf is a character that contributes towards resistance and hence effects the spider mite population. The data revealed that the highest thickness of leaf lamina was recorded in tolerance cultivar i. e. PDR-14, HUR-15, and also in IPR-98-31, while minimum thickness of leaf lamina were recorded on highly susceptible variety Gujarat Rajmah in open field condition, than from all other cultivar of French bean.

Length of leaf hair on French bean leaves has immense importance in resistance process and impairing spider mite population as they become unable to take their mouth parts at feeding sites. The data are regarding length of leaf hair in millimetre on leaf. The maximum length of leaf hair was recorded on highly tolerant plant i.e. PDR-14, HUR-15, and IPR98-31 in open field condition. Minimum lengths of leaf hair were recorded in cultivar Gujarat Rajmah. In open field condition the highest leaf hair length were recorded (0.05 $\mathrm{mm}$ ) in less susceptible cultivar PDR-14 and
IPR-98-31. Leaf hair density plays an important role on spider mite population as it hinders their feeding. The cultivar PDR-14 (47.00 mites $/ 2 \mathrm{~cm}^{2}$ leaf), HUR-15 (48.00 mites $/ 2 \mathrm{~cm}^{2}$ leaf) and (43.00 mites $/ 2 \mathrm{~cm}^{2}$ leaf), IPR-98-31 were recorded highest leaf hair density under poly house condition. The minimum leaf hair density were recorded on the cultivar Gujarat Rajmah (36.67 mites/2 $\mathrm{cm}^{2}$ leaf) followed by ArkaKomal (35.33 mites $/ 2 \mathrm{~cm}^{2}$ leaf). Whereas the maximum leaf hair density were recorded in tolerant variety PDR-14 (47.33 mites $/ 2 \mathrm{~cm}^{2}$ leaf) followed by in HUR-15 (43.00 mites/2 $\mathrm{cm}^{2}$ leaf) under open field condition, the minimum leaf hair length (31.67 mites/2 $\mathrm{cm}^{2}$ leaf) was recorded on Gujarat Rajmah, followed by (36.33 mites $/ 2 \mathrm{~cm}^{2}$ leaf) on IPR-98-5 variety of French bean. Misra et al., (1990) found a significant negative correlation between density of brinjal leaf and mite population. Further, Shah and Shukla (2013) also reported that on various gerbera cultivars, biomorphological character of plants play important role on spider mite population build-up. Thus, more or less closely support the present findings.

\section{Acknowledgement}

The authors are thankful to Professor and Head, Department of Entomology, N.M. College of Agriculture, Navsari, The Principal and Dean, N.M. College of agriculture, Navsari and Director of Research and Dean P.G. Studies for providing all the necessary facilities during the course of study.

\section{References}

Bhusal, S.B. 2011. Biology, population dynamics, varietal screening and chemical control of chrysanthemum mite (Tetranychus urticae Koch.). M.Sc. (Agri.) Thesis (Unpublished, Navsari Agricultural University, 
Navsari. pp. 114.

Hole, U.B. and Salunkhe, G.N. 2005. Studies on the relative resistance of rose cultivars to two spotted spider mite (Tetranychus urticae Koch.). J. Maharashtra Agric. Univ., 30(3): 316317.

Manjulata, K., Shashi, B., Varma, B.R., Kapur, M. and Bhalla, S. 2002. Pest risk involved in important of roses and its germplasm. Indian J. Ent., 64(4): 465470.

Meyer, M.K.P. and Rodriguez, M. 1966. Acari associated with cotton in Southern Africa. Revistadaj. de Inves Colultramar, 13: 1- 33.

Mishra, K.K., Sarkar, P.K., Das, T.K. and Somchoudhury, A.K. 1990. Incidence of Tetranychus cinnabarinus (Boisd.)(Acari: Tetranychidae) on some selected accessions of brinjal with special references to physical basis of resistance. Indian Agril., 34: 177-185.

Najafabadi, M.S. 2012. Resistance to Tetranychus urticae Koch (Acari: Tetranychidae) in Phaseolus vulgaris L. Middle-East J. Scientific Res., 11(6):
690-701.

Ramireddy, P.V., Janakiram, T. and Rao, T.M. 2004. Screening of chrysanthemum germplasm for resistance to two spotted spider mite, Tetranychus urticae Koch and bud borer, Helicoverpaarmigera (Hb.). J. Ornamental Hort., 7(1): 80-84.

Shah, D.R. and Shukla, A. 2013. Reaction of gerbera cultivars to spider mite, Tetranychus urticae Koch. (Tetranychidae: Acari) under polyhouse conditions. J. Pl. Pro. Sci., 5(2): 26-32.

Shukla, A. and Radadia, G.G. 2015. Reaction of carnation varieties to two spotted red spider mite, Tetranychus urticae Koch. (Tetranychidae: Acari) under polyhouse conditions. J. Exp. Zool. India, 19(1): 151-154.

Toke, N.R. 2010. Biology, population dynamics, varietal screening and chemical control of rose mite (Tetranychus urticae Koch.). M.Sc. (Agri.) Thesis (Unpublished, Navsari Agricultural University, Navsari. pp. 110.

\section{How to cite this article:}

Chauhan Rinkikumari and Abhishek Shukla. 2017. Varietal Screening of French Bean (Phaseolus vulgaris L.) Varieties against Spider Mite, Tetranychus urticae Koch under Field Condition. Int.J.Curr.Microbiol.App.Sci. 6(4): 1416-1422.

doi: https://doi.org/10.20546/ijcmas.2017.604.173 